JFFI. 2018; 5(1) 271-278

www.jurnal.farmasi.umi.ac.id/index.php/fitofarmakaindonesia

\title{
AKTIFITAS EKSTRAK JAHE MERAH DALAM MENURUNKAN ASAM URAT PADA KELINCI SERTA ISOLASI DAN IDENTIFIKASI SENYAWA BIOAKTIFNYA
}

\author{
Subehan Lallo ${ }^{1}$, Muhammad Mirwan ${ }^{2}$, Adrianti Palino ${ }^{1}$, Nursamsiar ${ }^{2}$, Besse Hardianti ${ }^{2}$ \\ ${ }^{1}$ Fakultas Farmasi, Universitas Hasanuddin \\ ${ }^{2}$ Sekolah Tinggi Farmasi Makassar \\ subehan@unhas.ac.id
}

\begin{abstract}
ABSTRAK
Jahe merah (Zingiber officinalle var. Amarum) merupakan salah satu tumbuhan yang banyak digunakan sebagai bumbu makanan sehari-hari dan juga berkhasiat sebagai obat tradisional untuk mengobati berbagai penyakit termasuk asam urat. Penelitian ini bertujuan untuk menguji aktifitas biologi dari jahe merah dan mengisolasi dan mengidentifikasi senyawa bioaktif yang tekandung di dalam ekstraknya. Berdasarkan penelitian yang dilakukan terhadap ekstrak etanol jahe merah memperlihatkan kemampuannya dalam menurunkan asam urat pada kelinci yang diinduksi dengan kalium bromat $\left(\mathrm{KBrO}_{3}\right)$ pada konsentrasi 0,6 b/v yang diamati pada 1 dan 3 jam setelah diinduksi dan dibandingkan dengan allopurinol yang digunakan sebagai positif kontrolnya. Ekstrak etanol jahe merah juga memperlihatkan hubungan konsentrasi dengan penurunan asam urat pada kelinci. Isolasi senyawa bioaktif dalam tanaman ini telah dilakukan dengan menggunakan metode kromatografi dan identifikasi stukturnya didasarkan pada analisis data spektrofotometri dan NMR. Berdasarkan data spectra yang diperoleh terhadap senyawa yang paling dominan yang berhasil diisolasi dan diidentifikasi adalah senyawa 6-gingerol. Hal ini menunjukkan bahwa ekstrak etanol jahe merah memiliki aktifitas dalam menurunkan kadar asam urat dengan senyawa utama 6-gingerol.
\end{abstract}

Keywords: Jahe merah, Zingiber officinalle var. Amarum, asam urat, 6-gingerol

\section{Pendahuluan}

Tumbuhan merupakan salah satu sumber terbesar dari alam yang digunakan sebagai obat tradisional dan menjadi objek penelitian dalam pencarian obat baru. Pemanfaatan tanaman untuk obat tradisional memiliki kelebihan tersendiri yaitu toksisitasnya rendah, mudah diperoleh, murah harganya dan kurang menimbulkan efek samping. Kelebihan ini juga telah dibuktikan secara empiris pada penggunaan langsung oleh manusia secara tradisional. Hal inilah yang menjadi salah satu motivasi untuk melirik kembali potensi alam untuk mengupayakan penanggulangan berbagai penyakit atau gangguan kesehatan yang sering muncul termasuk dalam proses pencegahannya. Indonesia termasuk negara dengan sumber keanekaragaman hayati terbesar di dunia. Kekayaan alam yang sangat berpotensi dan besar ini seharusnya mulai dilakukan pemberdayaan dan pemanfaatan serta penelitian mengenai obat tradisional untuk memberikan bukti ilmiah mengenai khasiat suatu tanaman obat dan juga dapat digunakan sebagai sumber senyawa penuntun "lead compound" untuk mensintesis senyawa obat baru. Kemajuan ilmu pengetahuan dan teknologi dibidang ilmu kefarmasian menimbulkan perkembangan dan inovasi penemuan obat baru yang berasal dari obat tradisional mulai berkembang pesat. Kesadaran masyarakat akan pentingnya kesehatan juga mengalami peningkatan, namun seiring dengan hal tersebut juga berkembang berbagai jenis penyakit akibat perubahan gaya hidup yang lebih modern dengan tingkat stres yang lebih tinggi. Munculnya resistensi terhadap berbagai jenis bakteri ataupun parasit mengakibatkan perlunya pengembangan dan penemuan obat baru. Kondisi lingkungan yang beriklim tropis juga sangat memungkinkan berbagai jenis penyakit untuk tumbuh berkembang. Salah satu gangguan kesehatan yang paling banyak muncul diusia lanjut adalah penyakit asam urat.

Asam urat merupakan suatu produk akhir dari metabolisme purin. Proses metabolisme purin sangat essensial bagi tubuh karena mampu menghasilkan komponen-komponen asam nukleat penting seperti DNA, RNA, dan kebutuhan energi sel yaitu ATP. Produk akhir dari proses metabolime ini menjadi bahan dasar untuk pembentukan asam urat yang merupakan senyawa yang sukar larut dan apabila terjadi pengendapan serta jumlah yang berlebih dalam darah (hiperurisemia) dapat 
menyebabkan gout (Vincent dkk, 2003). Asam urat dapat menjadi sumber penyakit bila kadarnya berlebihan dalam darah (>7 mg/dL) atau karena penurunan eksresi asam urat oleh ginjal, dapat pula karena kombinasi keduanya (Luk dan Simkin, 2005). Berbagai teknik pengobatan telah dilakukan untuk mengatasi penyakit ini termasuk penggunaan senyawa anti inflamasi seperti anti inflamasi non steroid (AINS) dan penggunaan senyawa penghambat enzim xanthin oxidase untuk mengurangi produksi asam urat. Beberapa kasus penggunaan anti inflamasi non steroid (AINS) dapat memberikan efek samping berupa retensi nitrogen dan hiperkalemia (Sarawek, 2007). Munculnya efek samping dan berbagai kekurangan dari berbagai obatobat modern yang digunakan saat ini menuntut untuk tetap mencari obat yang lebih mujarab dengan efek samping yang sekecil mungkin. Salah satu alternatif sumber bahan yang dapat dikembangkan untuk membuat bahan obat baru atau obat baru adalah obat tradisional.

Berbagai jenis tumbuhan obat yang telah terbukti secara empiris dapat menurunkan kadar asam urat. Salah satu tumbuhan yang digunakan untuk pengobatan tradisional untuk penyakit asam urat adalah jahe merah (Zingiber officinale var. Amarum). Jahe merah yang merupakan anggota famili Zingiberaceae merupakan tanaman yang mudah tumbuh di tempat terbuka seperti kebun dan pekarangan. Tanaman ini juga dapat tumbuh di tanah padat, kering ataupun gembur (Heinrich dan Subroto, 2000). Ada tiga jenis jahe yang telah dibudidayakan di Indonesia yaitu: Jahe Gajah (Zingiber officinale var. Officinale), Jahe Emprit (Zingiber officinale var. Rubrum) dan Jahe Merah (Zingiber officinale var. Amarum) (Wijayakusuma, 2006). Kegunaan praktis ketiganya kadang-kadang berbeda. Jahe gajah yang ukurannya besar, berkulit putih atau kuning dan rasanya tidak terlalu pedas dapat diolah sebagai manisan atau asinan. Jahe emprit yang ukurannya kecil, berkulit putih atau kuning dan sangat pedas sering digunakan untuk bumbu masakan dan obat. Jahe merah yang ukurannya sedang dan berkulit merah umumnya digunakan untuk obat. Di antara jahe gajah dan jahe emprit terdapat berbagai variasi ukuran jahe. Jahe ini paling umum ditanam dan sering diperdagangkan berdasarkan daerah asalnya (Sudemo, 2004).

Jenis Zingiber officinale var. Amarum merupakan jenis yang sangat populer digunakan sebagai bahan baku tradisional. Hal ini disebabkan karena kandungan minyak atsiri, zat gingeral, serta oleoresin atau zat yang memberikan rasa pahit dan pedas lebih tinggi dibandingkan dengan dua jenis jahe lainnya, yaitu jahe gajah dan jahe emprit. Jahe juga dapat digunakan pada industri obat, minyak wangi, dan sampai pada industri jamu tradisional (Herlina, 2004). Adapun manfaat dan kegunaan lain dari jahe merah secara empiris antara lain sebagai karminatif, anti muntah, pereda kejang, anti pengerasan pembuluh darah, peluruh keringat, anti inflamasi, anti mikroba dan parasit, anti piretik, anti rematik, serta merangsang pengeluaran getah lambung dan getah empedu (Harmono dan Andoko, 2005).

Berdasarkan uraian diatas, maka timbul suatu permasalahan yaitu untuk membuktikan secara ilmiah apakah ekstrak jahe merah (Zingiber officinale var. Amarum) memiliki kemampuan dalam menurunkan kadar asam urat pada hewan coba kelinci dan mengisolasi serta mengidentifikasi komponen kimia dari rimpang jahe merah. Adapun tujuan dari penelitian ini adalah untuk mengetahui senyawa atau komponen kimia bioaktif dari rimpang jahe merah dengan mengisolasi dan mengidentifikasi dan menguji aktivitas ekstraknya dalam menurunkan kadar asam urat. Manfaat penelitian ini adalah sebagai salah satu sumber informasi secara ilmiah pada bidang kefarmasian, tentang penggunaan rimpang jahe merah sebagai obat tradisional maupun modern dalam menyembuhkan berbagai penyakit.

\section{METODE PENELITIAN \\ A. Alat dan Bahan yang Digunakan}

Alat-alat yang digunakan dalam penelitian ini adalah lampu UV $254 \mathrm{~nm}$ dan $366 \mathrm{~nm}$, seperangkat alat kromatografi lapis tipis, alat sentrifus (Hettich), balon kateter, spektrofotometer UV-Vis, NMR (Jeol), Humalyser (human body), gelas arloji, labu tentukur $100 \mathrm{ml}$ (Pyrex), lumpang dan alu, pipet ukur, tabung darah, tabung sentrifuge, timbangan analitik (Sartorius), timbangan gram (O'hauss), timbangan hewan (Berkel), dan spoit.

Bahan-bahan yang digunakan dalam penelitian ini adalah air suling, etanol, jahe merah (Zingiber officinale Linn.Var.rubrum), n-heksan, etil asetat, ethanol $70 \%$, kertas saring, $\mathrm{H}_{2} \mathrm{SO}_{4} 10 \%$, silica gel, reagen Dragendroff, $\mathrm{H}_{2} \mathrm{SO}_{4} 2 \mathrm{~N}$, reagen Mayer, reagen wagner, serbuk $\mathrm{Fe}, \mathrm{HCl}$ pekat, eter, asam asetat anhidrat, $\mathrm{H}_{2} \mathrm{SO}_{4}$ pekat, $\mathrm{FeCl}_{3}$, silika gel, kalium bromat $\left(\mathrm{KBrO}_{3}\right)$, natrium $\mathrm{CMC}$, reagen untuk analisis asam urat dan tablet Allopurinol.

\section{B. Pengambilan dan Penyiapan Sampel}

Sampel jahe merah (Zingiber officinale Linn.Var.rubrum) diperoleh dari Tana Toraja, Sulawesi Selatan. Sampel dibersihkan kemudian diangin-anginkan pada tempat yang tidak terkena cahaya matahari langsung hingga mengering. Sebanyak kurang lebih $100 \mathrm{~g}$ sampel jahe merah yang telah kering, dipotong kecil-kecil kemudian dimasukkan dalam wadah maserasi, lalu 
ditambahkan dengan cairan penyari sampai sampel terendam seluruhnya. Ekstraksi dilakukan selam 5 hari, hasil ekstraksi yang diperoleh selanjutnya diuapkan hingga diperoleh ekstrak kental.

\section{Identifikasi Golongan Kimia Ekstrak 1. Uji Alkaloid}

Uji Alkaloid dilakukan dengan metode Mayer, Wagner dan Dragendorff. Sampel sebanyak 3 $\mathrm{mL}$ diletakkan dalam cawan porselin kemudian ditambahkan $5 \mathrm{~mL} \mathrm{HCl} 2 \mathrm{M}$, diaduk dan kemudian didinginkan pada temperatur ruangan. Filtrat yang diperoleh ditambahkan $\mathrm{HCl} 2 \mathrm{~N}$ sebanyak 3 tetes, kemudian dipisahkan menjadi 3 bagian A, B, C. Filtrat A ditambah pereaksi Mayer, filtrat B ditambah pereaksi Wagner, sedangkan filtrat $\mathrm{C}$ ditambah Dragendorf. Apabila terbentuk endapan pada penambahan pereaksi Mayer, Wagner dan Dragendorf maka identifikasi menunjukkan adanya alkaloid

\section{Uji Flavonoid}

Sebanyak $3 \mathrm{~mL}$ sampel diuapkan, dicuci dengan heksana sampai jernih. Residu dilarutkan dalam $20 \mathrm{~mL}$ etanol kemudian disaring. Filtrat dibagi 4 bagian A dan B. Filtrat A ditambahkan 0,5 mL HCl pekat kemudian dipanaskan pada penangas air, jika terjadi perubahan warna merah tua sampai ungu menunjukkan hasil yang positif (metode Bate SmithMetchalf). Filtrat B ditambahkan $0,5 \mathrm{~mL} \mathrm{HCl}$ dan logam $\mathrm{Mg}$ kemudian diamati perubahan warna yang terjadi (metode Wilstater). Warna merah sampai jingga diberikan oleh senyawa flavon, warna merah tua diberikan oleh flavonol atau flavonon, warna hijau sampai biru diberikan oleh aglikon atau glikosida.

\section{Uji Teroenoid dan Steroid}

Ekstrak dimasukkan sedikit dalam tabung reaksi kecil, lalu dikocok dengan sedikit eter. Lapisan eter diambil lalu diteteskan pada plat tetes, dan dibiarkan sampai kering. Setelah kering, ditambahkan dua tetes asam asetat anhidrat dan satu tetes asam sulfat pekat. Apabila terbentuk warna orange, merah, atau kuning berarti positif terpenoid. Tetapi apabila terbentuk warna hijau berarti positif steroid.

\section{Uji Saponin}

Uji Saponin dilakukan dengan metode Forth yaitu dengan cara memasukkan $2 \mathrm{~mL}$ sampel kedalam tabung reaksi kemudian ditambahkan $10 \mathrm{~mL}$ akuades lalu dikocok selama 30 detik, diamati perubahan yang terjadi. Apabila terbentuk busa yang mantap (tidak hilang selama 30 detik) maka identifikasi menunjukkan adanya saponin.

\section{Uji Fenolik}

Sejumlah kecil ekstrak dimasukkan ke dalam tabung reaksi kecil, lalu dikocok dengan sedikit eter. Lapisan eter dikeringkan pada plat tetes, ditambah larutan $\mathrm{FeCl}_{3}$. Terbentuk warna ungu biru berarti positif fenolik.

\section{Uji Tanin}

Ekstrak dimasukkan ke dalam tabung reaksi kemudian dikocok dengan air panas hingga homogen kemudian ditambahkan $\mathrm{FeCl}_{3}$. Jika berwarna hijau biru (hijau hitam) berarti positif adanya tanin katekol sedangkan jika berwarna biru hitam berarti positif adanya tanin pirogalol.

\section{Pengujian Aktivitas Asam Urat \\ 1. Penyiapan Suspensi Ekstrak Etanol Jahe Merah}

Ekstrak jahe merah akan diberikan dalam 3 variasi dosis yaitu $0,2 \% \mathrm{~b} / \mathrm{v}, 0,4 \% \mathrm{~b} / \mathrm{v}, 0,6 \% \mathrm{~b} / \mathrm{v}$. Untuk membuat suspensi ekstrak dengan konsentrasi $0,2 \% \mathrm{~b} / \mathrm{v}$, sebanyak $0,2 \mathrm{~g}$ ekstrak digerus dalam lumpang, ditambah larutan koloidal Natrium CMC $1 \%$ sedikit demi sedikit sambil digerus hingga homogen, lalu dimasukan ke dalam labu tentukur dan volumenya dicukupkan hingga $100 \mathrm{ml}$. Untuk membuat suspensi ekstrak dengan konsentrasi 0,4\% $\mathrm{b} / \mathrm{v}$ dan $0,6 \% \mathrm{~b} / \mathrm{v}$, diperlukan ekstrak masing-masing 0,4 dan 0,6 gram untuk $100 \mathrm{ml}$.

\section{Pemilihan dan Penyiapan Hewan Uji}

Hewan uji yang digunakan adalah kelinci jantan sebanyak 15 ekor dengan bobot badan 1,5-2 $\mathrm{kg}$ yang dibagi dalam 3 kelompok perlakuan yaitu kelompok 1 (kontrol negatif) yang diberi suspensi Natrium CMC 1\%, kelompok 2 (kontrol positif) yang diberi allopurinol, kelompok 3, 4, dan 5 diberi suspensi ekstrak etanol jahe merah dengan konsentrasi masing-masing $0,2 \% \mathrm{~b} / \mathrm{v}, 0,4 \% \mathrm{~b} / \mathrm{v}$, dan $0,6 \% \mathrm{~b} / \mathrm{v}$.

\section{Perlakuan Pada Hewan Uji}

Sebelum perlakuan hewan diadaptasikan dengan lingkungan selama 1-2 minggu, lalu ditimbang untuk mengetahui bobot badannya, kemudian dikelompokkan menjadi 3 kelompok yang masing-masing terdiri dari 3 ekor, lalu dipuasakan selama 8 jam. Ekstrak etanol jahe merah dari larutan stok di berikan secara per oral pada kelinci kelompok ke-3 (0,2 \%b/v), ke-4 (0,4\% b/v), ke-5 (0,6 \% b/v). Perlakuan kontrol diberikan untuk kelinci kelompok ke-1 (Natrium CMC 1\%) dan kelompok ke-2 (Allopurinol 0,058\% b/v).

Pengambilan dan pengukuran darah dilakukan pada masing-masing kelinci di tiap kelompok. Pengambilan dan pengukuran darah 
pertama kali dilakukan sebelum semua kelinci diberikan perlakuan. Pengambilan dan pengukuran darah yang kedua kali dilakukan setelah semua kelinci di induksi dengan $\mathrm{KBrO}_{3} 111 \mathrm{mg} / \mathrm{kg} \mathrm{BB}$. Pengambilan dan pengukuran darah yang ketiga kali dilakukan setelah pemberian obat dan sampel.

\section{Pengukuran Kadar Asam Urat dalam Darah} Cuplikan darah yang diperoleh $(1 \mathrm{ml})$ lalu disentrifuge selama 15 menit, akan diperoleh larutan supernatan yang kemudian diukur absorbsinya dengan menggunakan Humalyser.

\section{Pengumpulan dan Analisis Data}

Pengumpulan data berdasarkan hasil pengamatan dilanjutkan dengan analisis data secara statistik dengan menggunakan metode Rancangan Acak Lengkap (RAL) dan analisis lanjutan dengan metode uji Beda Jarak Nyata Duncan (BNJD).

\section{E. Isolasi Senyawa \\ 1. Kromatografi Lapis Tipis}

Lempeng yang telah diberi garis diaktifkan dalam oven dengan suhu $100{ }^{\circ} \mathrm{C}$ selama 15 menit. Ekstrak kental kemudian dilarutkan kedalam vial dengan pelarut, dan selanjutnya ditotolkan pada lempeng yang sudah diaktifkan. Dibuat eluen nheksan: etil asetat dimasukkan kedalam bejana setelah itu dijenuhkan dengan kertas saring kemudian dielusi. Dilakukan pengamatan pada penampakan noda dengan menggunakan UV $254 \mathrm{~nm}$ dan $366 \mathrm{~nm}$ serta pereaksi semprot $\mathrm{H}_{2} \mathrm{SO}_{4} 10 \%$.

\section{Kromatografi Kolom}

Kolom kromatografi terlebih dahulu dibilas dengan $\mathrm{n}$ heksan-etil asetat, dimasukkan sedikit kapas kedalam tabung bagian bawah Kolom kromatografi terlebih dahulu dibilas dengan $n$ heksan-etil asetat, dimasukkan sedikit kapas pada bagian bawah tabung kolom selanjutnya dipasangkan tegak lurus pada statif. Ke dalam tabung kolom dimasukkan sebanyak 30 gram sedikit demi sedikit silica gel sambil diketuk-ketuk tabung kolom hingga memadat.

Ke dalam lumpang digerus sebanyak 5 gram ekstrak kental dan ditambahkan sedikit demi sedikit silica gel dan pelarut, sambil di gerus hingga homogen. Kemudian dimasukkan ke dalam tabung kolom dan di elusi dengan eluen $n$ heksan : etil asetat dengan berbagai perbandingan. Hasil yang keluar ditampung dalam vial berupa beberapa fraksi. Diambil masing - masing fraksi dilakukan kromatografi dengan menggunakan eluen n-heksan : etil asetat. Fraksi yang memiliki kesamaan pada KLT digabung menjadi satu fraksi.

\section{HASIL DAN PEMBAHASAN}

Standarisasi dalam kefarmasian tidak lain adalah serangkaian parameter, prosedur dan cara pengukuran yang hasilnya merupakan unsur-unsur terkait paradigma kefarmasian, mutu dalam artian memenuhi syarat standar (kimia, biologi dan farmasi), termasuk jaminan batas-batas stabilitas sebagai produk kefarmasian umumnya. Dengan kata lain, pengertian standarisasi juga berarti proses menjamin bahwa produk akhir obat (obat, ekstrak atau produk ekstrak) mempunyai nilai parameter tertentu yang konstan dan ditetapkan terlebih dahulu. Terdapat dua faktor yang mempengaruhi mutu ekstrak yaitu faktor biologi dari bahan asal tumbuhan obat dan faktor kandungan kimia bahan obat tersebut (Depkes RI 2000).

Pada penelitian ini dimaksudkan untuk mengetahui pengaruh pemberian ekstrak etanol jahe merah (Zingiber officinale var. Amarum) terhadap kadar asam urat kelinci (Oryctolagus cuniculus) dan isolasi serta identifikasi senyawanya dengan menggunakan metode kromatografi dan spektrofotometri. Jahe merah diekstraksi dengan menggunakan metode maserasi dengan pelarut etanol $70 \%$. Pelarut ini merupakan pelarut polar yang dapat mengekstraksi lebih banyak kandungan kimia yang bersifat polar. Metode maserasi merupakan metode ekstraksi secara dingin dengan membiarkan pelarut atau cairan penyari masuk kedalam sel sampel secara difusi dan melarutkan senyawa dengan jarak kepolaran yang sama dengan etanol $70 \%$ dalam air yang kemudian keluar kembali dari sel tumbuhan yang dijadikan sampel dengan membawa senyawa kimia atau metabolic sekunder dari tanaman. Metode ini sangat sederhana namun butuh waktu yang lebih lama untuk proses penyariannya sehingga dapat mengakibatkan senyawa yang tersari yang bersifat kurang stabil akan terurai dan bahkan berubah bentuk menjadi senyawa lainnya. Ekstrak yang diperoleh kemudian diliofilisasi untuk menghilangkan penyarinya untuk menghasilkan ekstrak yang kering atau kental.

Pada penelitian uji bioaktifitasnya dilakukan pengujian kemampuan dari ekstrak jahe tersebut dalam menurunkan kadar asam urat pada kelinci. Penelitian ini menggunakan 5 kelompok hewan coba kelinci dimana kelompok pertama sebagai kontrol negatif diberikan $\mathrm{Na} \mathrm{CMC}$, kelompok kedua sebagai kontrol positif diberikan suspensi allopurinol, kelompok ketiga sebagai kelompok perlakuan diberikan suspensi ekstrak etanol jahe merah 0,2\% b/v, kelompok keempat sebagai kelompok perlakuan diberikan suspensi ekstrak etanol jahe merah 0,4\% b/v, dan kelompok kelima sebagai kelompok perlakuan diberikan suspensi ekstrak etanol jahe merah 0,6 \% b/v. Hewan coba kelinci mula-mula 
diukur kadar asam urat awal sebelum diberikan perlakuan, dengan tujuan untuk mengetahui kadar asam urat kelinci pada keadaan normal. Kemudian hewan coba kelinci diinduksi dengan kalium bromat $\left(\mathrm{KBrO}_{3}\right)$ dengan dosis $111 \mathrm{mg} / \mathrm{kg} \mathrm{BB}$ selama $72 \mathrm{jam}$ untuk menaikkan kadar asam urat darah. Mekanisme kerja dari kalium bromat yaitu dengan menginduksi hiperurisemia dan gout. Mekanisme hiperurisemia dari kalium bromat disebabkan adanya percepatan metabolisme purin dengan meningkatnya aktivitas xantin oksidase akibatnya kadar asam urat meningkat dalam darah (Watanabe dkk, 2004). Setelah itu diberikan perlakuan dengan pemberian suspensi ekstrak etanol jahe merah dengan konsentrasi berbagai variasi kelompok konsentrasi yang dibandingkan dengan kelompok control positif suspensi allopurinol 0,06 \% b/v dan Na CMC $1 \%$ b/v sebagai kontrol. Kadar asam urat darah kemudian diukur dengan humalizer untuk mengetahui efek pemberian masing-masing perlakuan terhadap kadar asam urat darah.

Pada penelitian ini digunakan kontrol positif suspensi allopurinol. Senyawa ini dipilih karena kemampuannya yang sangat efektif dalam menormalkan kadar asam urat dalam daran dan kemih yang meningkat (Tan dan Rahardja, 2002). Allopurinol merupakan senyawa alternatif yang digunakan untuk meningkatkan ekskresi asam urat melalui penghambatan enzim xantin oksidase dan 80 $\%$ diabsorbsi setelah pemberian oral. Seperti halnya asam urat, allopurinol sendiri dimetabolisme oleh xantin oksidase menjadi allantoxantin, mempertahankan kapasitas untuk mencegah xantin oksidase dan memiliki durasi efek yang cukup panjang sehingga terapinya cukup sekali dalam sehari (Katzung, 2001).

Berdasarkan persen penurunan kadar asam dari data pengamatan terlihat bahwa kelompok kontrol positif yang diberikan suspensi allopurinol memberikan efek penurunan kadar asam urat sebesar 54\%. Pada kelompok perlakuan yang diberi ekstrak etanol jahe merah 0,2\% mengalami penurunan kadar asam urat sebesar $26 \%$ dan pada kelompok perlakuan yang diberi ekstrak etanol jahe merah $0,4 \%$ mengalami penurunan kadar asam urat sebesar $37 \%$, dimana penurunan kadar asam uratnya masih lebih kecil daripada ekstrak etanol jahe merah $0,6 \%$ yaitu sebesar $43 \%$. Sedangkan kelompok kontrol negatif mengalami juga tetap menunjukkan penurunan kadar asam urat namun sangat kecil dibandingkan dengan semua jenis perlakuan yaitu sebesar $18 \%$.

Data hasil pengamatan menunjukkan bahwa ekstrak etanol jahe merah 0,6\% memberikan efek menurunkan kadar asam urat darah kelinci yang lebih besar daripada ekstrak etanol jahe merah 0,2\% dan ekstrak etanol jahe merah 0,4\%. Ini disebabkan karena flavonoid yang ada pada jahe merah menghambat kerja xantin oksidase sehingga tidak terbentuk asam urat. Efek flavonoid sebagai penghambatan enzim xantin oksidase tidak berlangsung lama karena cepat di ekskresi melalui urin.

Berdasarkan analisis statistik dengan menggunakan metode Rancangan Acak Lengkap (RAL) dan Analisis Sidik Ragam (ASR) memperlihatkan bahwa pemberian ekstrak etanol jahe merah memberikan efek yang sangat nyata (sangat signifikan) terhadap penurunan kadar asam urat pada hewan coba kelinci yang dapat dilihat dari besarnya $\mathrm{F}$ hitung yang lebih besar daripada $\mathrm{F}$ tabel. Kemudian dilanjutkan dengan uji lanjutan menggunakan uji Beda Nyata Jarak Duncan (BNJD) diperoleh bahwa ekstrak etanol jahe merah dengan konsentrasi $0,6 \% \mathrm{~b} / \mathrm{v}$ memberikan efek yang berbeda sangat nyata dengan kontrol negatif dan ekstrak etanol jahe merah dengan konsentrasi $0,2 \%$, hal ini berarti ekstrak etanol jahe merah dengan konsentrasi $0,6 \% \mathrm{~b} / \mathrm{v}$ memberikan efek penurunan yang lebih baik daripada kontrol negatif dan ekstrak etanol jahe merah dengan konsentrasi $0,2 \%$. Serta berbeda nyata dengan ekstrak etanol jahe merah dengan konsentrasi $0,4 \% \mathrm{~b} / \mathrm{v}$, hal ini berarti efek penurunan ekstrak etanol jahe merah dengan konsentrasi $0,6 \% \mathrm{~b} / \mathrm{v}$ lebih besar dari ekstrak etanol jahe merah dengan konsentrasi $0,4 \% \mathrm{~b} / \mathrm{v}$ tetapi berbeda tidak nyata dengan kontrol positif (allopurinol), hal ini berarti antara kontrol positif dengan ekstrak etanol jahe merah dengan konsentrasi $0,6 \%$ b/v memberikan efek penurunan yang hampir sama. 


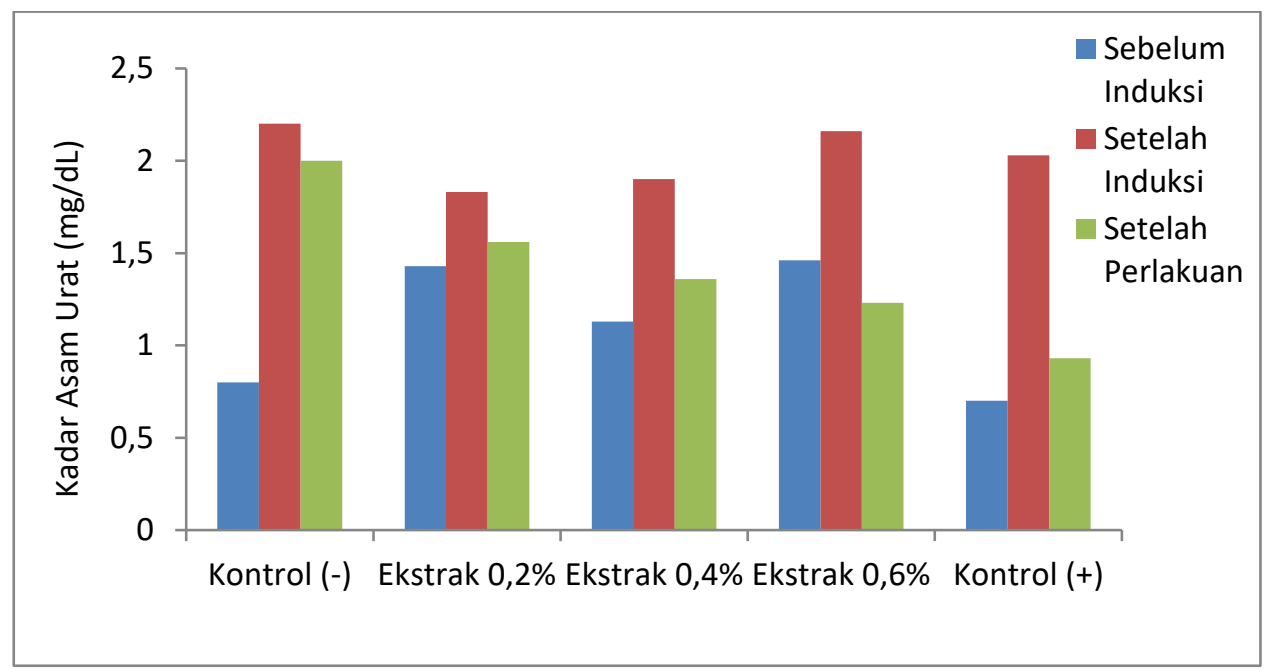

Gambar 1. Penurunan Kadar Asam Urat dalam darah Kelinci

Telah dilaporkan bahwa ekstrak etanol daun singkong (Manihot utilissima Pohl.) dengan konsentrasi 25\% dapat menurunkan kadar asam urat dengan persen penurunan sebesar $27 \%$ (Julianti, 2010). Berdasarkan hasil penelitian yang diperoleh dibandingkan dengan penelitian sebelumnya dapat disimpulkan bahwa ekstrak etanol jahe merah (Zingiber officinale Linn.Var.rubrum) dengan konsentrasi 0,6\% mempunyai kemampuan lebih baik dibandingkan dengan ekstrak etanol daun singkong (Manihot utilissima Pohl.) dalam menurunkan kadar asam urat dengan persen penurunan sebesar $43 \%$.

Penelitian selanjutnya dilakukan untuk mengisolasi senyawa bioaktif dari rimpang jahe merah dan mengidentifikasi struktur senyawanya dengan menggunakan spektrofotometer UV dan NMR. Sebelum proses pemisahan senyawa, dilakukan terlebih dahulu orientasi eluen dengan menggunakan pelarut Metanol, Heksan, Etil asetat, dan Kloroform. Orientasi dilakukan menggunakan kromatografi lapis tipis (KLT) dengan adsorben yang digunakan berupa Silika gel 40 F254. Hasil orientasi menunjukkan eluen Heksan : Etil asetat (4:3) memberikan pemisahan yang baik, kemudian dilakukan uji identifikasi golongan terhadap ekstrak rimpang Jahe Merah. Dari hasil identifikasi golongan, ekstrak Heksan rimpang Jahe Merah positif mengandung Tanin dan Saponin.

Berdasarkan profil KLT, heksan:etil asetat (4:3) adalah merupakan eluen terbaik dalam pemisahan senyawa ini kemudian dilakukan Fraksinasi dengan menggunakan Kromatografi kolom konvensional, dengan fase diam silica gel 40 dan eluen yang berupa komposisi pelarut heksan:etil asetat dengan perbandingan 100:0, 90:10, 80:20, 70:30, dan 60:40. Hasil fraksinasi ditampung dalam vial dengan masing-masing ukuran $10 \mathrm{ml}$ menghasilkan berjumlah 30 vial yang selanjutnya disebut subfraksi.

Subfraksi yang telah diperoleh kemudian dipantau kembali dengan KLT dengan menggunakan eluen heksan:etil asetat 4:3. Subfraksi 1, 5, 10, 15, 20 dan 30 yang merupakan perwakilan dari 30 vial untuk dilakukan KLT. Hasil KLT menunjukkan bahwa penampakkan noda terdapat pada subfraksi 1 dan 15 sehingga memungkinkan untuk dilakukan KLT kembali pada subfraksi 1 sampai 15 . Kromatografi diamati dibawah UV pada $254 \mathrm{~nm}$ dan $366 \mathrm{~nm}$. Serta digunakan penampak bercak asam sulfat $10 \%$. Hasil pemantauan dengan kromatografi lapis tipis menunjukkan adanya pemisahan bercak-bercak dengan jumlah dan nilai Rf yang berbeda-beda dari masing-masing subfraksi. Hal ini membuktikan bahwa proses pemisahan komponen kimia berdasarkan tingkat kepolarannya sudah terjadi. Subfraksi yang memiliki kesamaan profil KLT disatukan yakni subfraksi 8, 9, 10, 11, 12, 13, 14 dan 15 sehingga memungkinkan untuk dilakukan penggabungan fraksi, kemudian diuapkan. Selanjutnya, fraksi gabung diamati kembali menggunakan KLT, dengan fase gerak heksan-etil asetat 4:3, fase diam silica gel 40 dan penampak noda menggunakan UV $254 \mathrm{~nm}$, UV $366 \mathrm{~nm}$, dan dengan penyemprotan $\mathrm{H}_{2} \mathrm{SO}_{4}$. Dari hasil pengamatan diperoleh 1 fraksi dengan nilai Rf 0,60, dengan UV $254 \mathrm{~nm}$ dan UV $366 \mathrm{~nm}$ memberikan penampakan noda berwarna ungu, dan dengan pereaksi semprot $\mathrm{H}_{2} \mathrm{SO}_{4}$ menghasilkan warna cokelat. 


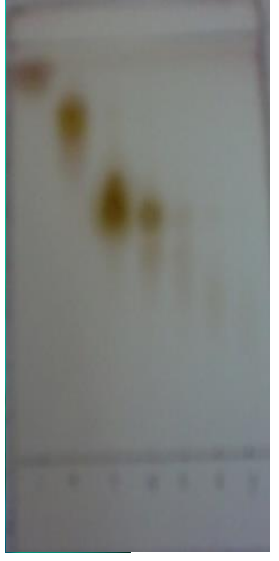

A

Gambar 2. Hasil KLT (A) Fraksi ekstrak jahe merah dengan penampak noda $\mathrm{H}_{2} \mathrm{SO}_{4}$. (B) Isolat dengan penampak noda sinar UV $254 \mathrm{~nm}$ dan $\mathrm{H}_{2} \mathrm{SO}_{4}$ pada lempeng KLT silica gel dielusi dengan hexan:EtoAc (4:3).

Data H-NMR (400 MHz) terhadap senyawa yang diisolasi menunjukkan adanya signal $\delta_{\mathrm{H}} 0.87$ $(3 \mathrm{H}, \mathrm{t}, \mathrm{J}=6.8 \mathrm{~Hz}, \mathrm{H}-10), 1.25-1.40(8 \mathrm{H}, \mathrm{H}-6,7,8,9)$, $2.50(1 \mathrm{H}, \mathrm{d}, \mathrm{J}=8.8 \mathrm{~Hz}, \mathrm{H}-4 \mathrm{a}), 2.54(1 \mathrm{H}, \mathrm{d}, \mathrm{J}=3.2 \mathrm{~Hz}$, H-4b), 2.74 (2H, d, J=7.1 Hz, H-2), 2.82 (2H, d, J=7.1 $\mathrm{Hz}, \mathrm{H}-1), 3.86$ (3H, s, OCH $), 4.03$ (1H, m, H-5), 6.65 $(1 \mathrm{H}, \mathrm{dd}, \mathrm{J}=8,1,9 \mathrm{~Hz}, \mathrm{H}-6$ ') 6.67 (1H, d, 1,9 Hz, H2'), 6.81 (1H, d, J=8 Hz, H-5'). Hal ini menunjukkan adanya gugus metil primer pada $\delta_{\mathrm{H}} 0.87$ yang ditandai dengan multiplicity triplet dengan 8 proton metilen pada $\delta_{\mathrm{H}} 1.25-1.40$ serta 2 proton metilen lainnya yang berada pada posisi yang lebih bergeser kearah downfield (deshielded) $\delta_{\mathrm{H}} 2.50(1 \mathrm{H}, \mathrm{d}, \mathrm{J}=8.8 \mathrm{~Hz}, \mathrm{H}-$ 4a), 2.54 (1H, d, J=3.2 Hz, H-4b), dan 4 proton lainnya pada $\delta_{\mathrm{H}} 2.74(2 \mathrm{H}, \mathrm{d}, \mathrm{J}=7.1 \mathrm{~Hz}, \mathrm{H}-2), 2.82$ ( $2 \mathrm{H}, \mathrm{d}, \mathrm{J}=7.1 \mathrm{~Hz}, \mathrm{H}-1)$. Keberadaan satu gugus metoksi ditandai dengan munculnya signal pada $\delta_{\mathrm{H}}$ $3.86\left(3 \mathrm{H}, \mathrm{s},-\mathrm{OCH}_{3}\right)$ dengan ciri signal intensitas tinggi sebanyak 3 proton. Proton teroksigenasi juga terdeteksi dengan munculnya sinyal pada $\delta_{\mathrm{H}} 4.03$ $(1 \mathrm{H}, \mathrm{m}, \mathrm{H}-5)$. Gugus aromatis terlihat pada daerah yang lebih deshielded dengan geseran kimia yang lebih besar dari 6 ppm. Pada data H-NMR menunjukkan keberadaan signal tersebut berupa aromatic dengan ABX system pada $\delta_{\mathrm{H}} 6.65(1 \mathrm{H}$, dd, $\mathrm{J}=8,1,9 \mathrm{~Hz}, \mathrm{H}-6$ '), 6.67 (1H, d, 1,9 Hz, H-2'), 6.81 $\left(1 \mathrm{H}, \mathrm{d}, \mathrm{J}=8 \mathrm{~Hz}, \mathrm{H}-5^{\prime}\right)$. Berdasarkan data H-NMR ini dan dengan membandingkan dengan beberapa literature yang telah dilaporkan sebelumnya menunjukkan senyawa tersebut adalah 6-gingerol (Hou Wo, 2007). Senyawa ini memang banyak ditemukan dalam tanaman dari family Zingiberaceae termasuk pada tanaman jahe (Zingiber officinale) atau pada lempuyang wangi (Zingiber aromaticum) yang merupakan senyawa bioaktif dengan berbagai aktifitas biologi yang telah dilaporkan (Subehan, 2005).<smiles>CCCCC[C@H](O)CC(=O)CCc1ccc(O)c(OC)c1</smiles>

Gambar 3. Struktur kimia 6-Gingerol

\section{KESIMPULAN}

Penelitian ini membuktikan bahwa ekstrak etanol jahe merah (Zingiber officinale Var. Amarum) pada konsentrasi $0,6 \%$ b/v memiliki kemampuan paling baik untuk menurunkan kadar asam urat pada hewan uji kelinci serta 6-gingerol merupakan senyawa bioaktif yang diisolasi dari ekstrak etanol jahe merah.

\section{UCAPAN TERIMA KASIH}

Terima kasih kepada Laboratorium Natural Products Chemistry, Institute of Natural Medicine, University of Toyama atas dukungannya dalam pengukuran data spektra H-NMR terhadap isolat yang diperoleh.

\section{DAFTAR PUSTAKA}

Vincent M.F., Marie S., Race V., Timmerman T., 2003. Purine Metabolism. Hospital SaintLuc University. pp.13-17.

Luk J. A., Simkin A. P., 2005. Epidemiology of Hyperuricemia and Gout. The American Journal of Managed Care. pp. 11, S435S442.

Sarawek S., 2007. Xanthine Oxidase Inhibition and Antioksidant Activity Of An Artichoke Leaf Extract (Cynara scolymus L.) And its Compounds. A Dissertation Presented To The Graduate School Of The University Of Florida In Partial Fulfillment Of The Requirements For The Degree Of Doctor Of Philosohy. University Of Florida. p. 19, 21, 25.

Heinrich M., Subroto A., 2000. Gempur Penyakit dengan Minyak Herbal Papua. Agromedia Pustaka. Jakarta. pp. 5-8.

Wijakusuma H., Sehat dengan Jahe. http://www.suarakarya.online/news. Diakses 13 agustus 2006.

Sudemo B., 2004. Tanaman Obat Populer, Penggempur Aneka Penyakit. Agremedia Pustaka Pesona. pp. 1-12.

Herlina R., Murhananto, Endah J., Listyarini S.P., Pribadi S.T., 2004. Khasiat Dan Manfaat 
Jahe Merah si Rimpang Ajaib. Agromedia Pustaka. pp. 1-12.

Harmono, Andoko A., 2005. Budidaya dan Peluang Bisnis Jahe, Penerbit Agromedia Pustaka.

Watanabe S., Tajima Y., Yamaguchi T., Fukui T., 2004. Potassium Bromate-Induced Hyperuricemia Stimulates Acute Kidney Damage Oxidative Stress. Journal of Health Science. 647-653.

Tan H.T., Rahardja K., 2002. Obat-Obat Penting, Khasiat, Penggunaan dan Efek-Efek Sampingnya. ed.5. PT. Elex Media Komputindo Gramedia. Jakarta.. Hal. 319, 321-322

Katzung B. G. 2001. Farmakologi Dasar dan Klinik. Ed. 8. Terjemahan oleh Bagian Farmakologi Fakultas Kedokteran Universitas Airlangga. Salemba Medika. Jakarta. Hal 487 - 490

Julianti T.B. 2010., Pengaruh Pemberian Ekstrak Etanol dan Infus Daun Singkong (Manihot utilissima Pohl.) terhadap Kadar Asam Urat Kelinci (Oryctolagus cuniculus). Skripsi. Fakultas Farmasi Universitas Hasanuddin. Makassar. pp. 34-36.

HouWu, 2007. Isolation And Characterization Of Natural Products From Ginger And Allium ursinum. A Dissertation Submited To The Graduate School-New Brunswick Rutgers, The State University Of New Jersey. In Partial Fulfillment Of The Requirements For The Degree Of Doctor Of Philosohy. Graduate Program In Food Science. P. 81.

Subehan, Usia T., Kadota S., Tezuka Y., 2005. Constituents of Zingiber aromaticum and Their CYP3A4 and CYP2D6 Inhibitory Activities. Chemical and Pharmaceutical Bulletin, 53(3). pp. 333-335. 